\title{
TUDÁSMENEDZSMENT \\ A MAGYARORSZÁGI BANKOKBAN
}

A szerző 2006 elsố felében végrehajtott banki tudásmenedzsment-felmérésében arra kereste a választ, vajon a hazai bankok milyen szinten ismerik és alkalmazzák a tudásmenedzsment kelléktárát. Összességében a magyar banki helyzetre elmondható, hogy vannak még bốven tartalékok a tudásmenedzsment népszerúsítése és stratégiai szempontú felhasználása terén.

Kulcsszavak: tudásmenedzsment, bank, interjú

A Magyarországon tevékenykedő 30 bank és 8 speciális hitelintézet életét is jelentősen befolyásolják a világban lezajló változások. A globalizáció hatásait a banki felvásárlásoknál, összeolvadásoknál lehet megfigyelni. Nálunk is jellemzô, hogy méretgazdaságossági szempontok alapján az egyre nagyobb versenyzők tudnak csak piacon maradni. A magyar bankszektorban túlnyomó részben a külföldi tulajdonú bankok dominálnak. Érdekes módon, míg a fejlett nyugat-európai országokban a gazdaságosabb elektronikus csatornák bevezetésének hatására a fiókok számának csökkentése jellemző, addig nálunk jó néhány nagybank intenzív módon alakítja ki hazai fiókhálózatát.

$\mathrm{Az}$ információtechnológia és a kommunikációs technológiák nagyon gyors fejlődésének hatására egyre több banki szolgáltatást ajánlanak a magyar bankok is elektronikus csatornákon keresztül. Az internet és a mobil technológiák ma már alapkövetelményként jelennek meg, s a hagyományos banki szolgáltatások mellett egyre fontosabb bevételi forrásokká válnak. A magyarországi bankok számára egyre fontosabbak lesznek a kis- és középvállalatok (KKV), valamint a lakossági üzletág. Az ügyfelek alapos ismerete nélkülözhetetlen ahhoz, hogy testre szabott szolgáltatásokat tudjanak nyújtani, s a keresztértékesítésben rejlő új bevételi forrásokat is kihasználhassák. Az ügyfelek kiszolgálásának másik fontos eleme a gyors és minőségi szolgáltatások kialakítása. Egyre több bank hirdetésében jelenik meg az időtényezô kiemelése. A hitelnyújtási idô lecsökkentésének feltétele a gyors döntéshozatal, a jól szabályozott folyamatok és a jól múködő informatikai rendszerek együttmúködése.

A versenyben maradás feltétele az innovatív termékek minél gyorsabb kifejlesztése, azok eladásához új marketingmódszerek kidolgozása. Az új termékek kifejlesztéséhez jól képzett, a piacot jól ismerô szakemberekre van szükség, valamint megfelelóen rugalmas információtechnológiai támogatásra. A fenti tendenciák fényében a bankokra is igaz, hogy az egyetlen hoszszú távon fenntartható versenyelóny a konkurenseknél gyorsabb tanulás és a tudással való jobb gazdálkodás lehet. A komplex kihívásra az élenjáró bankok is a tudásmenedzsment alkalmazásával válaszolhatnak.

\section{A felmérés módszertana}

A 2005. december és 2006. június között végrehajtott banki tudásmenedzsment felmérésem arra kereste a választ, hogy a hazai bankok milyen szinten ismerik és alkalmazzák a tudásmenedzsment kelléktárát. Felmérésemet informatikai vezetốk megkérdezésére alapoztam. Ennek egyrészt az volt az oka, hogy a TM sok helyen jellemzően az IT vagy a HR terület felelősségi körébe tartozik, másrészt az a tény, hogy ebben a körben rendelkeztem jelentős ismeretségi körrel. A felmérésem egyik korlátozó tényezője is ebból következik, vagyis, hogy a megkérdezettek köre egy szakterület képviselóire korlátozódott. A felmérés elemzésénél ezt a tényt próbálom minden esetben kellôképpen kihangsúlyozni. Ugyanakkor úgy gondolom, hogy a felmérés reprezentatív volta (38 pénzintézet- 
ból 30 részt vett) megfelelố mértékben ellensúlyozza a korlátozó tényezôt. A résztvevoókkel megállapodtam abban, hogy az eredmények publikálásánál anonim adatokat mutatok be, azaz az adott bank válaszai sehol nem lesznek nevesítve, csak az összesített eredményekben mutatkoznak meg.

A felmérésben részt vevő 30 bank és szakosított pénzintézet informatikai vezetôit, vagy olyan esetekben, ahol nem volt elsố számú IT-vezetô, ott valamelyik IT terület vezetôjét (pl. IT-infrastruktúra, vagy fejlesztési vezető) kerestem meg. A megkeresettek közel egyharmadát már korábban személyesen ismertem, míg a másik egyharmadot ajánlások alapján, a harmadik harmadot pedig telefonos megkeresés után sikerült megnyernem. A felmérésben való részvételt egyértelmúen elősegítette, hogy a majdani eredményeket, illetve a bankok számára megfogalmazott ajánlásaimat minden esetben felajánlottam.

Az interjúk 20 perctől 2 óráig tartó személyes megbeszélések keretében zajlottak. A beszélgetés elején nagyvonalakban elmondtam, mit is gondolok tudásmenedzsment alatt, hogy a résztvevóknek értelmezhetóbbek legyenek a kérdéseim. Tudásmenedzsment alatt gyakorlatilag minden, a tudással történő tudatos törődést, foglalkozást értettem. A TM jobb megértése kapcsán megemlítettem még a talán legismertebb folyamatalapú megközelítés lépéseit, azaz a tudás feltérképezését, a tudáscélok meghatározását, a tudásteremtést, a tudás tárolását, a tudás megosztását és a tudás felhasználását. A kérdőív kitöltését együtt végeztük olyan módon, hogy amikor valami értelmezési probléma adódott, vagy példákra volt szükség, akkor besegítettem. Ahogy a fent leírt interjúidőintervallumok is jelzik, az érdeklődéstól függóen egészen kimerítő beszélgetések is kialakultak a témáról. A beszélgetések segítettek a kérdőív értelmezésében, valamint úgy gondolom, a tudásmenedzsment ismertetését is elősegítették. A visszajelzések is igazolták, hogy az informatikai vezetők fontos területnek tartják a tudásmenedzsmentet.

\section{A felmérés ismertetése}

A felmérések önmagukban nem mondanak sokat, fontosak az összehasonlítások is, azonban tudtommal a magyar banki szektor tudásmenedzsment-felmérését még senki nem végezte el, ezért az egyedi eredményeket kell értelmeznem. Mivel rendelkezésre állnak magyarországi tudásmenedzsment-felmérések eredményei (KPMG, 2000, 2002, 2005), ezért ott, ahol ezt relevánsnak tartom, megpróbálom összehasonlítani azokkal a banki válaszokat.

\section{A tudásmenedzsment sikertényezói}

Ön szerint bankjában mennyire ismert a tudásmenedzsment fogalma?

Mielőtt bármilyen mélyen belemennénk a tudásmenedzsment rejtelmeibe, érdekelt, mennyire ismert a fogalom a bankokban. A felmérés eredménye azt mutatta, hogy közepesnél kicsit rosszabb osztályzatot adtak a válaszolók. A válaszok összhangban vannak a KPMG 2005-ös felméréséból idézett legfontosabb tudásmenedzsmenttel kapcsolatos problémával: ,a TMelőnyök ismeretének hiánya" (KPMG, 2005). A magyar nyelvü szakirodalom jellemzésénél is kiemeltem, hogy jelentek meg alapművek (Davenport - Prusak, 2001; Sveiby, 2001), azonban vannak még bőven lehetóségek a TM ismertetésére. Reményteli az a tény, hogy egyre több egyetem oktatási tervében jelenik meg tudásmenedzsment-oktatás, így a jövőben felnövekvő új nemzedékeknek lehetősége lesz bővebb ismeretek megszerzésére (1. ábra).

\section{Bankjában mennyire ismert a tudásmenedzsment} fogalma?

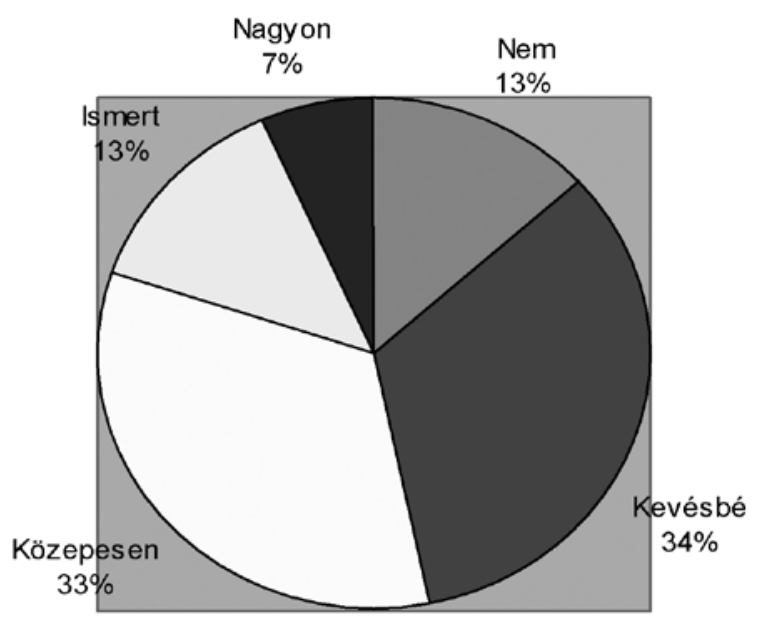

(Válaszát 1-5 terjedô skálán adja meg - 1: NEM - 5: NAGYON)

\section{Van-e bankjának tudásmenedzsment-stratégiája?}

Sajnálatos módon a helyzet nem nevezhető túl jónak, sốt azt is mondhatnánk, hogy igen elenyésző azoknak a bankoknak a száma (4), ahol van TM-stratégia. A TM-stratégiával rendelkező bankok 13\%-os aránya sokkal szerényebb, mint a KPMG 2005-ös felmérésének 37\%-os eredménye (KPMG, 2005). Nehéz azonban összehasonlítani a két eredményt, ugyanis a KPMG internetes felmérésében részt vevő 130 cég ugyan elég jelentôs számúnak mondható, azonban azzal a feltételezéssel élek, hogy nagy valószínúséggel a felmérés- 
ben inkább olyan cégek vettek részt, amelyek közelebb állnak, vagy elörehaladottabbak a TM területén, s ezért ekkora az eltérés. Habár a KPMG felmérésében megemlítik, hogy szinte minden iparág képviseltette magát, azonban a válaszolók köréról a méreteken túl több információ nem állt rendelkezésre. Nagyon sok függ a válaszadói kör összetételétôl. Ugyanis, ha jelentős számban olyan cégeket kértek fel, amelyekról köztudott, hogy foglalkoznak a tudásmenedzsmenttel, akkor a helyzet mást mutat. Azért tartom elképzelhetőnek az előző feltételezésemet, mert a KPMG 2000-es és 2002es felmérésében részt vevô 18-20 cégrôl kiemelték, hogy a tudásmenedzsmenthez közel állóak, s már az akkori felmérésekben 39\%-os volt a TM stratégiával rendelkezók aránya. A banki válaszoknál viszont nagyon biztató, hogy a szervezetek 30\%-a tervezi TM stratégia megalkotását (2. ábra).

2. ábra

Van-e bankjának tudásmenedzsment stratégiája?

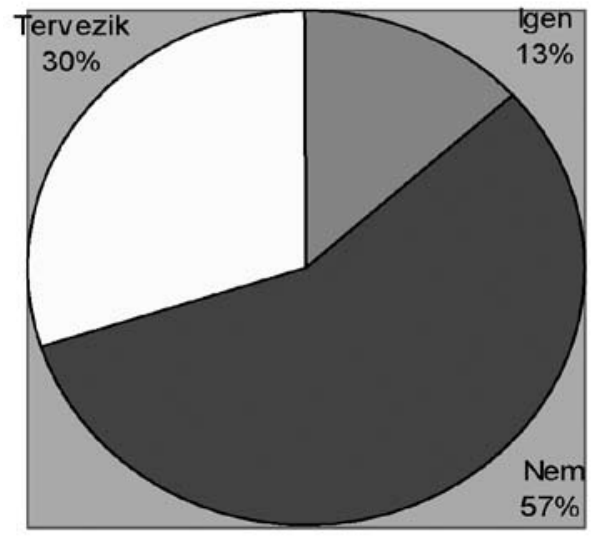

(Válaszok: 1: Igen, 2: Nem, 3: Tervezik)

Véleménye szerint mennyire értékelik bankjában a szakértói tudást?

A szakértôi tudást kiemelkedő fontosságúnak ítélik a bankok. Gyakorlatilag a válaszadók 90\%-a fontosnak, illetve nagyon fontosnak tartja azt. Nagyon tanulságos képet kapunk, ha összevetjük a tudást fontosnak tartó válaszokat és a késóbbiekben elénk táruló tudásmenedzsment-helyzetból adódó képpel. Hogyan lehet az, hogy ilyen jelentős mértékben tartják fontosnak a tudást, s mégsem foglalkoznak intenzívebben a tudás menedzselésével? Talán ez a kérdés az, amelyet a banki menedzsmentnek alaposabban meg kellene fontolnia. A válaszok értékelésénél ki kell emelni, hogy informatikai vezetôk válaszoltak, azaz elképzelhető, hogy csak saját területükön fontos a szakértői tudás, míg a bank más területein kevésbé (3. ábra).
3. ábra

Véleménye szerint mennyire értékelik bankjában a szakértôi tudást?

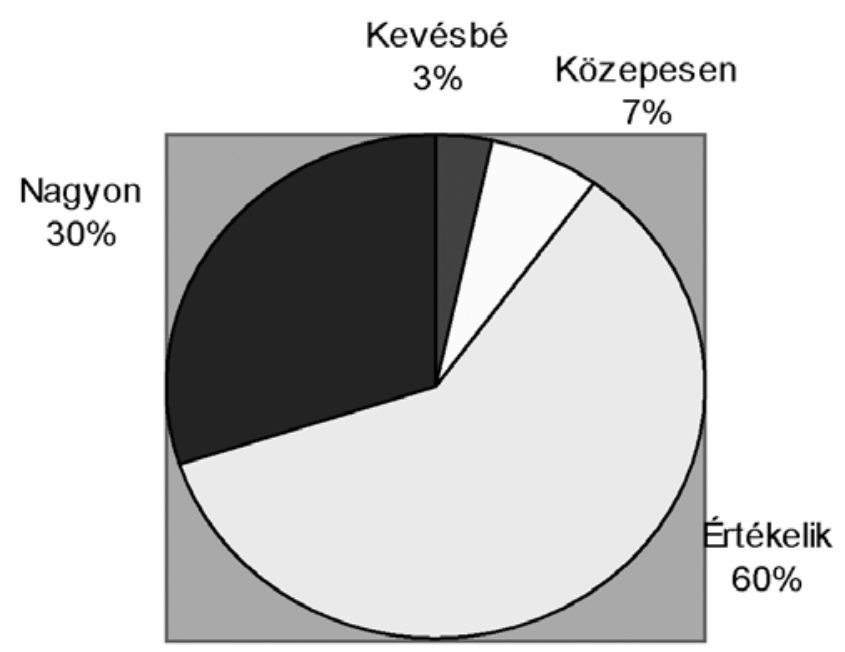

(Válaszát 1-5 terjedő skálán adja meg - 1: NEM - 5: NAGYON)

Véleménye szerint mennyire támogatja a bank szervezeti kultúrája a tudás megosztását?

A szervezeti kultúra fontosságát nagyon sok tudásmenedzsmenttel foglalkozó szerzố kiemeli. Olyan szervezeteknél, ahol a „tudás hatalom” felfogás érvényesül, szerény sikerre számíthat a tudásmenedzsment. A magyar banki helyzet ezen a területen aránylag jónak mondható, a válaszadók 33\%-a közepesen, míg 43\%-a határozottan tudásmegosztást támogatónak tartja bankja szervezeti kultúráját. Egy kis ellentmondás fedezhetó fel abban, hogy a 12. kérdésnél a tudásmenedzsmentet hátráltató tényezốknél a válaszadók 2 . helyre rangsorolták a „Tudásmenedzsmentet támogató kultúra hiányát”. Magyarázatot adhat erre az ellentmondásra az a tény, hogy a rangsorolós kérdéseknél sokszor nem a saját bankra vonatkoztatták a kérdéseket, hanem elvi síkon próbálták megválaszolni azokat (4. ábra).

Motiválják vagy jutalmazzák-e a dolgozókat a tudásuk megosztásakor?

A tudásmegosztás alapfeltétele a bizalom megléte a szervezeten belül, s egy olyan szervezeti kultúra, amely támogatja azt. Azonban a tudásmegosztást segítheti a megfelelő motivációs rendszer megléte is. A banki válaszokból az derül ki, hogy közepes mértéknél gyengébbnek tartják a motiválást. A válaszadók közel $50 \%$-a válaszolt közepes arányú, míg 43\%-a inkább a kevésbé, vagy egyáltalán nem motiválják kategóriába sorolta bankját. A kérdés rámutat arra a kibontakozó képre, hogy nem foglalkoznak kelló mértékben tuda- 
Véleménye szerint mennyire támogatja a bank szervezeti kultúrája a tudás megosztását?

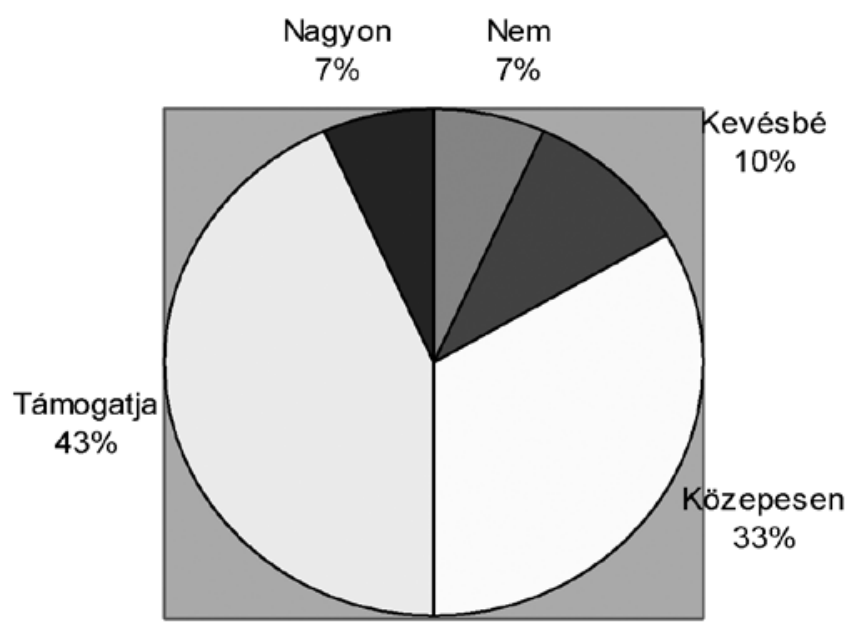

(Válaszát 1-5 terjedô skálán adja meg - 1: NEM - 5: NAGYON)

Motiválják vagy jutalmazzák-e a dolgozókat a tudásuk megosztásakor?

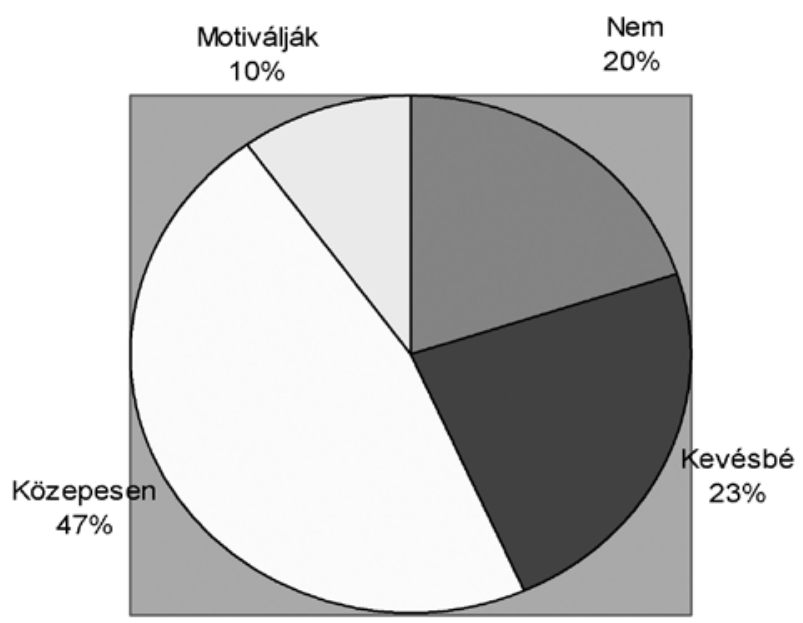

(Válaszát 1-5 terjedő skálán adja meg - 1: NEM - 5: NAGYON)

tosan a tudással a hazai bankokban, hiszen ha fontos a tudás, akkor annak megosztását is motiválni kellene a jobb eredmények elérése érdekében (5. ábra).

Van-e bankjukban jelenleg futó tudásmenedzsmentprogram? (Igen/Nem)

(pl. Tudásvagyon felmérése / Tudásbázis kialakítása / Szakmai közösségek / Best Practice (legjobb gyakorlat) megosztása / TM tudatosítása / Tudásközpontok létrehozása stb.)
A fenti kérdésnél a példákat direkt emeltem ki, hogy ezzel is segítsem a válaszadókat abban, mit is értünk TM-programok alatt. A válaszadók túlnyomó többségénél $(87 \%)$ vannak futó tudásmenedzsmentprogramok. A felmérés során egyre tapasztaltabban világítottam meg a kérdéseket, $\mathrm{s}$ egyre érzékletesebb példákat hoztam. Elképzelhetô, hogy a „nem”-mel válaszoló 4 banknál is vannak tudásmenedzsment-kategóriába sorolható programok, csak az adott idôpontban esetleg még nem voltam elég meggyőzó a példáimmal. Összességében azonban megállapítható, hogy szinte mindegyik bankban foglalkoznak a tudásmenedzsment területéhez sorolható tevékenységekkel.

Amennyiben van tudásmenedzsment-program, kérem, sorolja fel azokat

A tudásmenedzsment programok rangsorát közel 30\%-os arányokkal az „oktatás, tréning, képzés”, „best practice (legjobb gyakorlat) megosztása” és a „tudásbázis kialakítása" vezeti. A leggyakrabban előforduló oktatás, tréning, képzés kategóriában nagyon széles kört értettek bele a válaszadók. Nagyon sok bankban van belsố akadémia, ahol különbözó előadás-sorozatokat tartanak. Találkoztam több olyan esettel is, ahol az egyes területek szakemberei adtak elő kollégáiknak a saját szúkebb szakterületükról. A képzések másik csoportja a külsố szakmai képzések, illetve a szervezetfejlesztési és tanácsadó cégek trénerei által tartott összekovácsoló, kommunikációs és csapatmunka-fejlesztô tréningek voltak (6. ábra).

Tudásbázisok alatt legtöbbször az informatikai területen összegyújtött, különbözô adatbázisokban, táblázatkezelókben vagy HelpDesk rendszerek tudásbázisaiban eltárolt tudás összességére gondoltak.

A kérdés elején bemutatott példák vagy nagyon találóak voltak, vagy pedig a válaszadók hajlamosak voltak azokból választani. Ezt a feltételezést abból vonom le, hogy a 4. és az 5. helyen közel 20\%-os aránnyal szerepelő „Szakmai közösségek” és a „Tudásközpontok létrehozása" is a kiemelt példák közé tartoztak. Anyitott kérdésre, hogy milyen programok vannak, igen sokféle válasz érkezett. Ezek összegzése, csoportosítása alapján foglaltam össze a grafikonban a válaszokat. Fontos megjegyezni itt is egy kis ellentmondást. Habár a jelen kérdés TM-programokra vonatkozott, a válaszokban megemlített technológiákra, IT-megoldásokra jóval szerényebb számú szavazat jutott, mint a kérdőív utolsó kérdésénél a használt technológiákra vonatkozóan. Kiemelném a vállalati portált, amelyet a technológia résznél $60 \%$ által standard eszköznek, s 30\%-ban bizonyos részlegek által használtnak tekintettek, addig 


\section{A bankban futó tudásmenedzsment-programok}

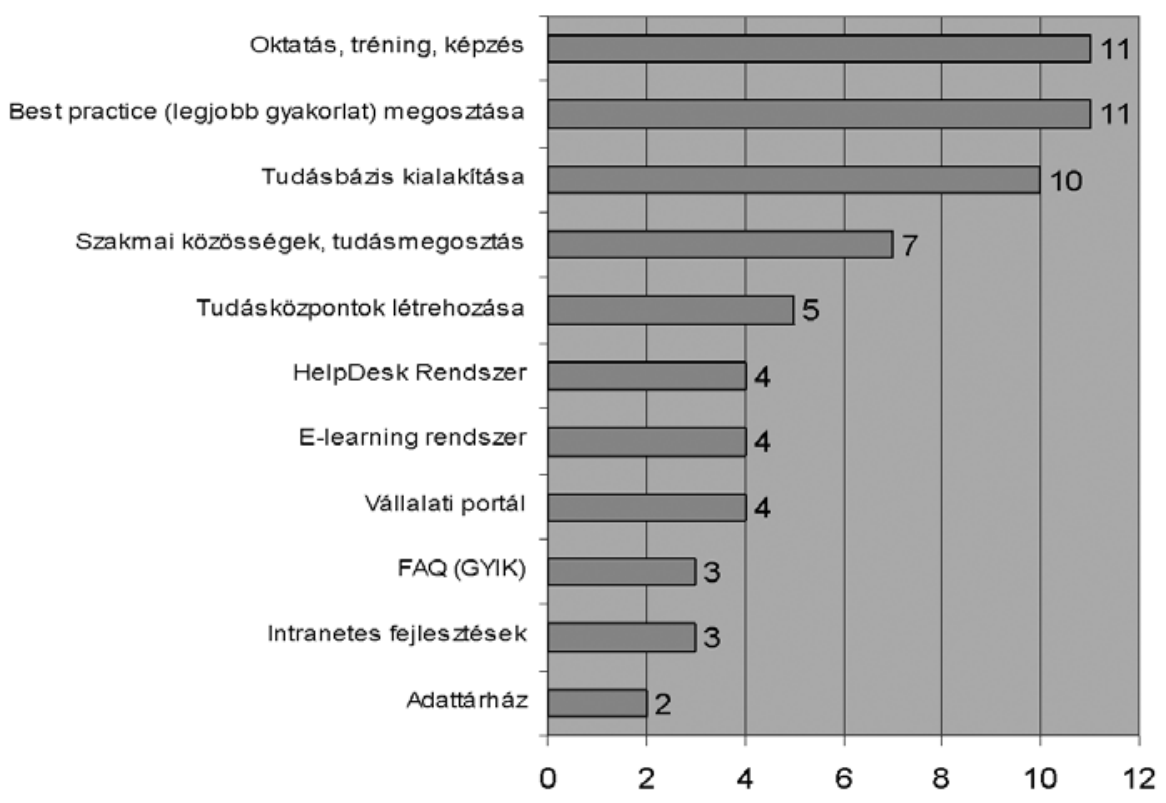

6. ábra 2005-ös felmérésében is, ahol a sort a „Formális információs csatornák kialakítása" vezeti $47 \%$-os aránynyal, míg a tudásközpontok, tudásbázisok létrehozása, és a szakmai közösségek 30-30\%-os arányban következnek (KPMG, 2005).

Tervezik-e a jövóben a TM-program bevezetését? (Igen/Nem)

A felmérésben részt vevő 30 bankból 22-ben tervezik valamilyen tudásmenedzsment-program beindítását, míg 8 bankban nincs ilyen szándék.

Amennyiben terveznek TM programot, kérem, sorolja fel azokat

A legtöbb válaszadó a bankban már futó tudásmenedzsment programok továbbfejlesztését jelölte

a jelen kérdésnél csak szerény 13\%-os arányt képviselt. Persze az is igaz, hogy a vállalati portál standard volta feltételezheti, hogy azon a területen már nem kell

\section{A bankban tervezett tudásmenedzsment-programok}

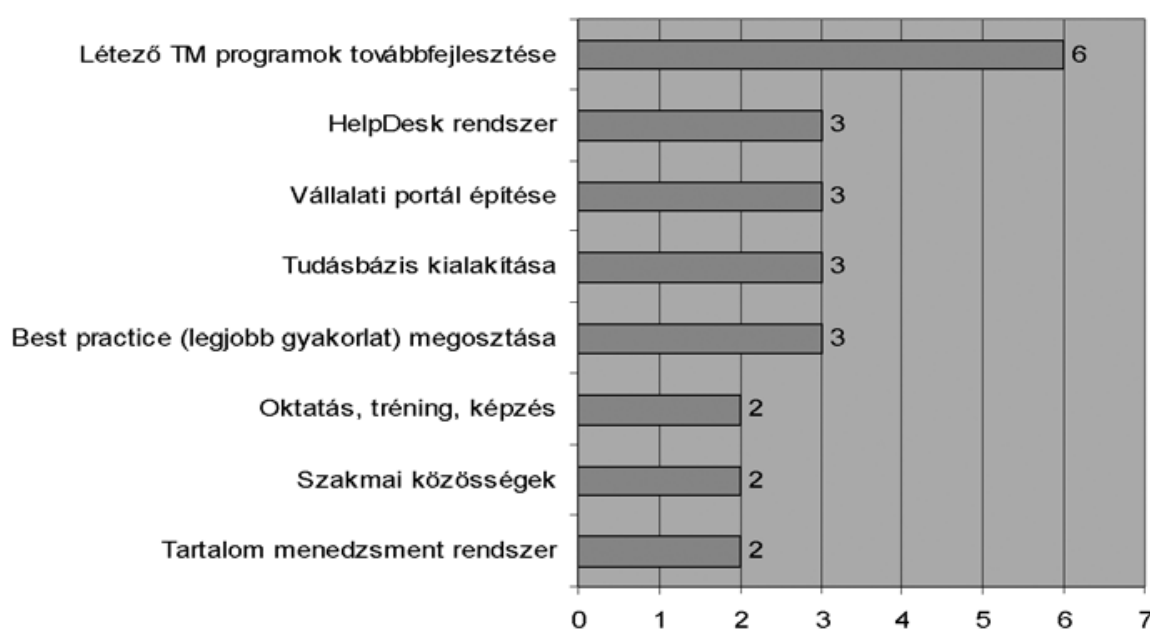
meg arra vonatkozóan, milyen terveik vannak a jövőre nézve. A grafikont az előzó, már futó TM-programok grafikonjával összehasonlítva az derül ki, hogy a tervezett konkrét TM-programok szinte ugyanarra a körre vonatkoznak, mint amit már a létezô kezdeményezéseknél láttunk. Érdekes módon a tervek között nem szerepel a tudásmenedzsment-stratégia megalkotása, amelyet a TM-stratégiára vonatkozó kérdésnél még a válaszadók 30\%-a tervezett. A tervezett programokra is jellemzô az egységes szemlélet hiánya, azaz független kezdeményezésekként kezelik ôket a bankok (7. ábra).

Amennyiben van, illetve terveznek TM programot, kik támogatják azt a bankban?

A tudásmenedzsment programokat támogatók köre 41\%-ban a felsó vezetók, míg 31\%-ban a középvezetôk köréből kerül ki. A tudásmenedzsment programok támogatása alatt azt értették, hogy maga a program kezdeményezése az adott szinten történik. A felsôvezetôi támogatást minden tudásmenedzsmenttel foglalkozó könyvben, cikkben kiemelik, így a jövốre nézve a 41\%-os támogatottság jó elôjel (8. ábra). 


\section{A tudásmenedzsment támogatása}

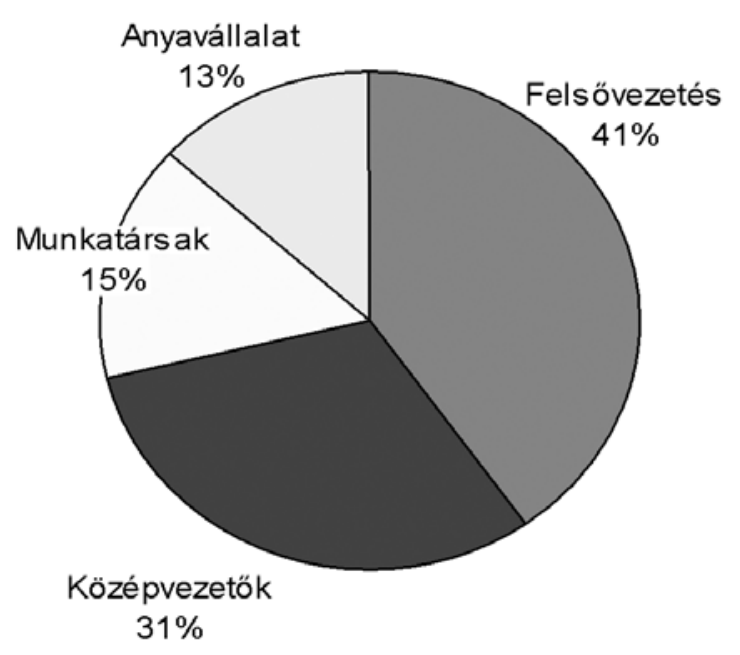

Válaszok:

Felsôvezetés / Középvezetốk / Munkatársak / Anyavállalat

\section{Milyen összefüggés van a bank sikeressége} és a tudásmenedzsment között?

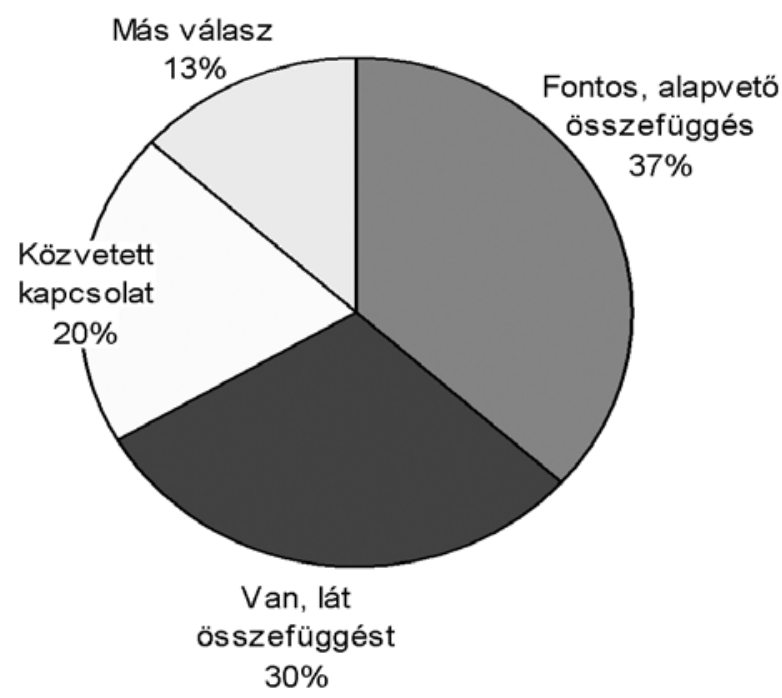

Fontos fejlemény, hogy a munkatársaktól is indulnak (15\%) tudásmenedzsment-kezdeményezések. A hazai bankok nagy része külföldi tulajdonossal rendelkezik, sokszor maga a tudásmenedzsment kezdeményezés is az anyabanktól származik (13\%). A felmérés során a külföldi tulajdonú bankoknál sokszor az anyabank tudásmenedzsment-programjait, kezdeményezéseit is felsorolták a válaszadók. Összehasonlításként érdekesek a KPMG 2005-ös felmérésének adatai, amelyben a felsővezetôi támogatás 50\%, míg a középvezetôi 20\%, a munkatársak $21 \%$ és az anyavállalatok 10\%-ban támogatták a programokat (KPMG, 2005).

Milyen összefüggés van a bank sikeressége és a tudásmenedzsment között?

A megkérdezettek egyértelmú összefüggést látnak a bank sikeressége és a tudásmenedzsment között. A válaszadók 37\%-a fontos, alapvető összefüggést, míg 30\%a lát kapcsolatot a sikeresség és a TM között (9. ábra).

A válaszadók $20 \%$-a gondolja úgy, hogy közvetett a kapcsolat. A válaszoknál nyitott kérdést tettem fel, amire mindenki saját szavaival próbált meg válaszolni, legtöbbször csak az informatikusokra jellemzố rövid tömörséggel, pl. „Igen, látok összefüggést” vagy „,Szoros az összefüggés".

Idézek még néhány érdekesebb választ: „Szoros a kapcsolat a tudásmenedzsment és a sikeresség között, a tudásmegosztás alapvetô követelmény, az eredményesség alapvetô feltétele”. „A kollégák tudása a bank legfontosabb termelőereje. Ennek megtartása és megosztása alapvetố a sikeresség szempontjából”. ,,Szerintem még nincs szoros összefüggés, amíg ez nem érzékelhető és igazolható konkrét versenyelőnyben, addig nem nevezhetô szorosnak".

A tudásmenedzsment és a sikeresség összefüggésére adott pozitív válaszok alapján arra következtethetünk, hogy a jövóben egyre több bank kezd el a területtel intenzívebben foglalkozni. Kérdés, hogy a gyakorlat alá fogja-e támasztani ezt a vélekedést?

\section{Melyek a kritikus tudásterületek a bankban?}

A kritikus tudásterületek meghatározása alapvetô fontosságú abból a szempontból, hogy a jövő́beni tudásmenedzsment-kezdeményezéseket e területeken ajánlott végrehajtani. A kérdés megválaszolása nehéz feladat elé állította a válaszadókat. Példákat kellett felhoznom, mit is érthetünk kritikus tudásterület alatt. A válaszoknál megadott 66\%-os arány az IT mint kritikus tudásterület mellett elgondolkodtató. Vajon a válaszadók „hazabeszéltek", és mint informatikai vezetók az IT elsődlegességét vallották, avagy valóban elsődleges az informatika? Mint informatikai területen dolgozó személy én is elfogult vagyok, azonban azt gondolom, hogy a bankokban az informatikai tudás alapvetô, még ha nem is ilyen mértékben. A klasszikus banki funkciók, tevékenységi körök követik az informatikát, mint a Sales, Back Office és a Treasury területek. Érdekesnek tartom, hogy akikért a bankok oly nagyon versenyeznek, azaz az ügyfelek, nem lettek megnevezve mint elsődleges tudásterület. Igaz, a Sales, Front Office és a Termékfejlesztés területek az ügyfelekre vonatkoznak (10. ábra). 


\section{Kritikus tudásterületek a bankban}

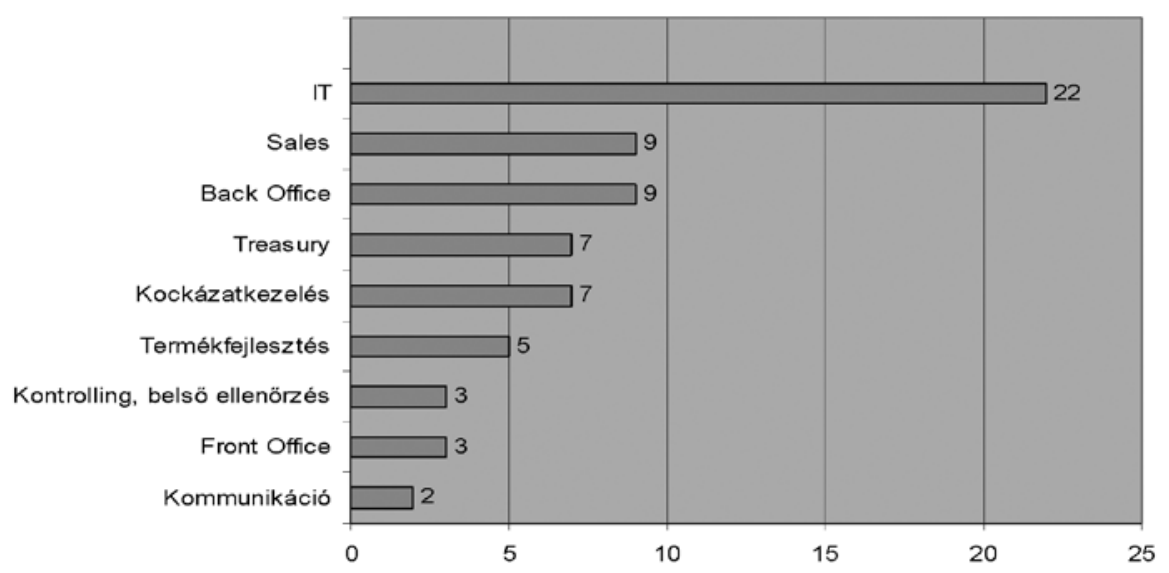

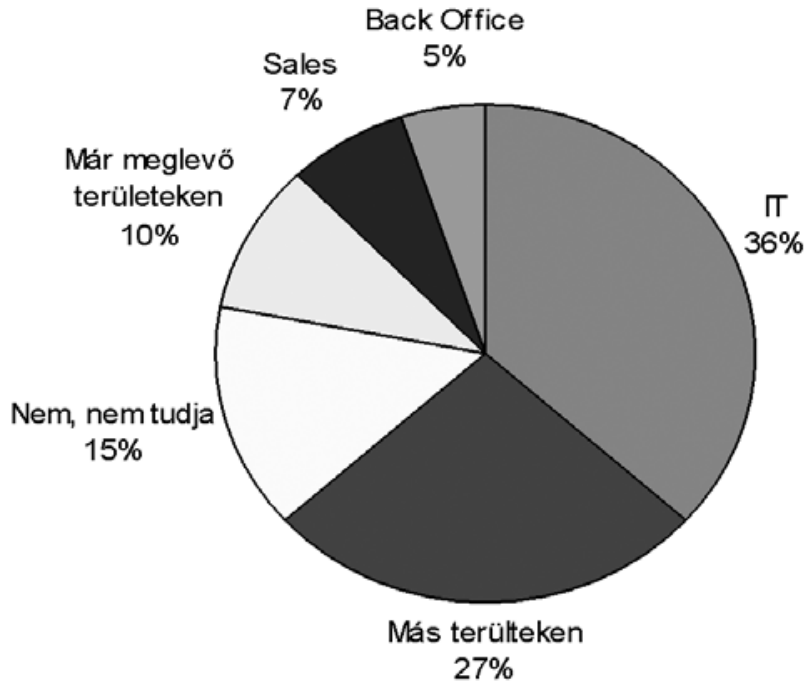

A fent megjelölt tudásterületeken terveznek-e valamely tudásmenedzsment programot?

Az előzô kérdés megfogalmazásának az volt az alapja, hogy a kritikus tudásterületek azonosítása alapvető a jövôbeli tudásmenedzsmenttevékenységek kapcsán, hiszen e területeken kellene erôsíteni. Gyakorlatilag a válaszadók is visszaigazolták ezt a gondolkodásmódot, mert itt is az IT, majd
10. ábra a Sales és a Back Office területeken terveznek túlnyomó részben TM-programokat. A kritikus tudásterületekre és a tudásmenedzsment e területeken történô fejlesztésére adott válaszokban kis bizonytalanságot tapasztaltam. Ennek a bizonytalan válasznak lehetséges oka, hogy a válaszadó informatikai vezetôk nem feltétlenül érzik saját területüknek az üzletre vonatkozó stratégiai kérdések megválaszolását, vagy csak azért voltak határozatlanabbak, mert nem foglalkoztak még a fenti kérdésekkel korábban (11. ábra).

\section{Tudásmenedzsmentet hátráltató tényezók}

Rangsorolja az alábbi felsorolásban a tudásmenedzsmentet leginkább hátráltató tényezóket!

A résztvevôknek rangsorolni kellett 1-tôl 12-ig, mely problémát tartják a tudásmenedzsmentet leginkább hátráltató tényezőnek. Toronymagasan a „Nincs idő a tudás megosztására" problémát tartották a legjelentősebbnek. Rohanó, teljesítményorientált világunkban én személy szerint is az idő hiányában látom nagyon sok probléma kiváltó okát (12. ábra).

A KPMG 2005-ös felmérésében is ezt az okot emelték ki a második helyen, míg ott elsôdleges problémának ,a TM-előnyök ismeretének hiányát" tartották a megkérdezettek (KPMG, 2005), ami a jelen felmérésben a 3 . helyen szerepelt. A felmérésben második helyre sorolt probléma a „Tudásmenedzsmentet támogató kultúra hiánya", azaz a szervezeti kultúra területén van

12. ábra

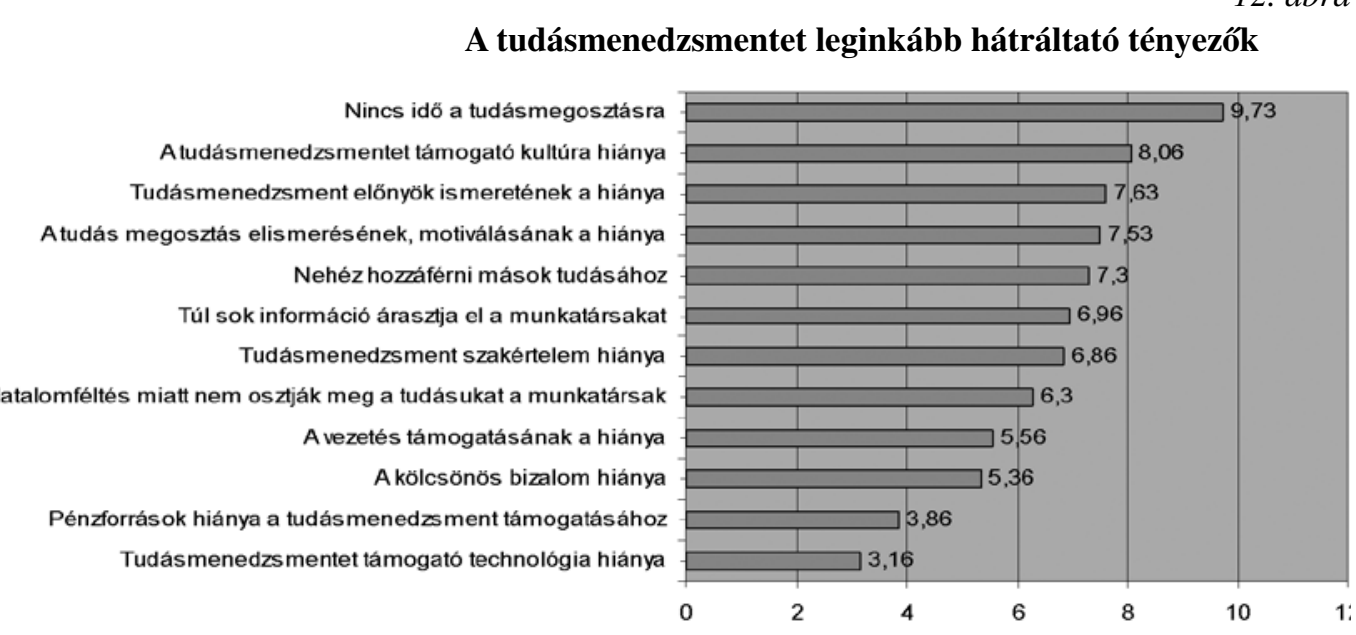

(Válaszában 1. a leginkább hátráltató - 12. a legkevésbé hátráltató tényező) 
még fejlődnivaló. Fontos megjegyezni, hogy ugyanakkor aránylag kevesen jelölték meg a hatalomféltés miatti tudásmegosztás-problémát, valamint a kölcsönös bizalom hiányát. A legkisebb problémának a támogatáshoz szükséges pénz és a támogató technológia hiányát jelölték meg. Már a 2000-es magyar KPMGfelmérés kiemelte azt, hogy technológia-területen nincs probléma itthon, a támogatottság aránya megegyezik a fejlett országokban mért értékekkel (KPMG, 2000).

\section{Tudásmenedzsment segítségével elvárt elốnyök}

Rangsorolja az alábbi felsorolásban, mely elönyöket lehet elérni a tudásmenedzsment alkalmazásával!

A résztvevóknek rangsorolni kellett 1-tôl 12-ig, mely előnyöket lehet elérni a tudásmenedzsment alkalmazásával. Talán ez volt a legnehezebb kérdés, ugyanis a felsorolt elốnyök nagyon erôsen összefüggenek egymással. A válaszadók egyik része egy logikai sorrend felállításával próbálta megragadni, melyek az elsôdleges előnyök, és ebból mi következik. A válaszadók másik része a bankja szempontjából elérhetô előnyöket rangsorolta a saját preferencia sorrendjének megfelelően. Ennél a kérdésnél, ahogy néhány másiknál is, hangsúlyozták, hogy a sorrend saját szubjektív véleményük, amely nem feltétlenül egyezik meg a bank egészének véleményével (13. ábra).

\section{A tudásmenedzsment által elérhetố elốnyök}

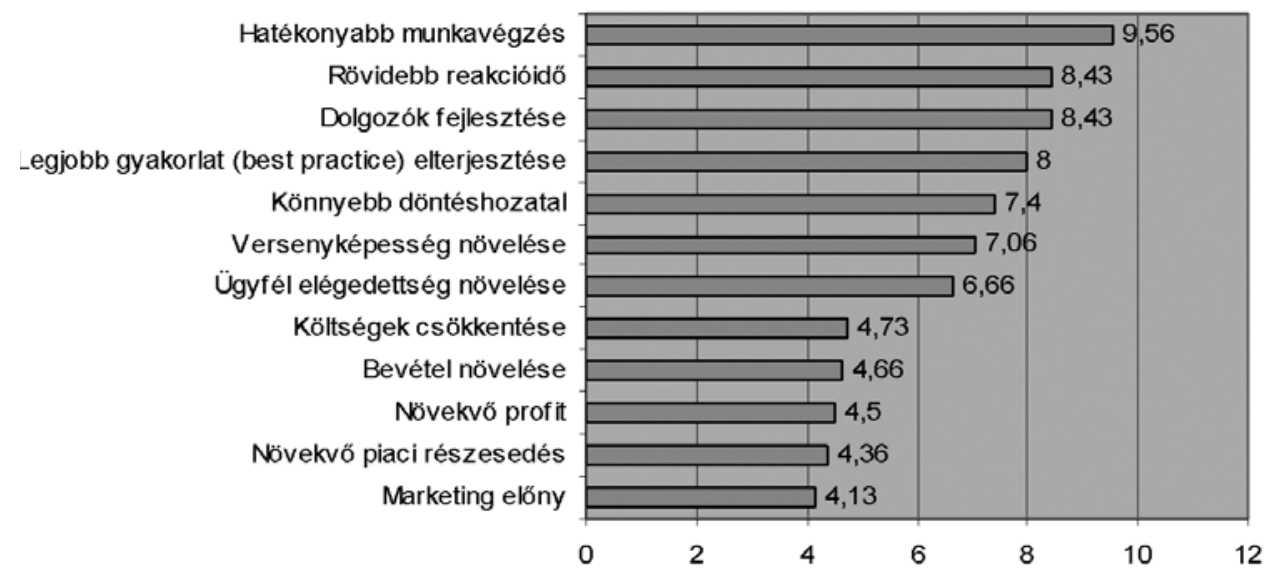

(Válaszában 1. a legfontosabb - 12. a legkevésbé fontos tényező)

A legfontosabb TM által elérhető előnynek a hatékonyabb munkavégzést tartották. Ezt követte a rövidebb reakcióidő, a dolgozók fejlesztése és a best practice (legjobb gyakorlat) elterjesztése. Érdekes módon kevesebb szavazatot kapott a versenyképesség és az ügyfél elégedettség növelése. A válaszoknál figyelembe kell venni, hogy az informatikai vezető́k inkább a háttérfolyamatok támogatását tartják fontosabbnak. Számukra a költség csökkentése és a bevételre, profitra, valamint a marketingelónyre vonatkozóak voltak a kevésbé fontos előnyök.

\section{Tudásmenedzsmentet támogató eszközök, technológiák, módszerek}

Jelölje be az alábbi felsorolásból mely technológiák, módszerek állnak rendelkezésre bankjában jelenleg, s milyen mértékú a bankban az adott eszköz használata!

A tudásmenedzsmentet támogató technológiákat, módszereket tudatosan tettem a kérdőív végére, hogy az informatikai vezetóket a válaszoknál ne a technológiai szemlélet vezesse. Az általam összegyújtött technológiák, eszközök, módszerek száma jóval több, mint amelyeket a KPMG felméréseiben felsorolnak (KPMG, 2000, 2005). Próbáltam a szakirodalomban fellelhető minél több támogató technológiát megnevezni, hogy ezzel is támogassam a válaszadókat. A válaszoknál jelezni lehetett, mennyire általános az adott eszköz használata. A válaszokat a standard eszközök sorrendje szerint mutatom be.

A legáltalánosabban használt támogató eszközök a vállalati intranet $90 \%$ feletti aránnyal, majd ezt követi a vállalati portál $66 \%$-kal. Azaz a bankoknál a tudás megosztását, valamint a tudás felhasználását támogató

\section{3. ábra} technológiákra helyezik a nagyobb hangsúlyt. Fontos kiemelni, hogy a bankokban valószínúleg biztonsági szempontból került 60\%kal csak a harmadik helyre a KPMG 2005-ös felmérésében $92 \%$-kal első helyre rangsorolt internethasználat. Standard eszköznek sorolhatjuk a csoportmunka támogatását is.

Felmérésemból látható, hogy a szükséges alaptechnológiák mindenképpen rendelkezésére állnak a megfelelő részlegekben, így az adott területek hozzáférnek külsô tudásbázisokhoz, szakmai adatbázisokhoz (cégtárak, jogtárak, KHR-rendszer), hírforrásokhoz (pl. a Reuters, Bloomberg rendszerekhez), valamint a döntéstámogatáshoz használt eszközök is megtalálhatóak. A tudás feltárását, új tudás létrehozását támogató technológiák közül a megfelelő részlegeken használják az adattárházakat és az adatbányászati eszközöket. 
A tudás feltérképezése során az elektronikus formában elérhetô tudás-objektumok tárolásához és megosztásához használják a tudásbázisokat, és kisebb mértékben ugyan, de tudásportálokat is. A hasznos tudással rendelkezô egyének feltérképezésére és elérésüket támogató vállalati tudástérképek azonban igen kis számban találhatók meg a pénzintézeteknél (14. ábra).

\section{Összegzés, jövốbeli lehetôségek}

Összességében a magyar banki helyzetre elmondható, hogy vannak még bőven tartalékok a tudásmenedzsment népszerúsítése és stratégiai szempontú felhasználása terén. A meglevố és a tervezett tudásmenedzsment-tevékenységek szigetszerúen, nem egységes stratégia mentén indulnak. A szervezeti

14. ábra kultúra alapvetôen támogatja a tudás megosztását, azonban a motivációs rendszerek nem ösztönzik azt kellóképpen. A tudásmenedzsmentet hátráltató tényezốknél - a legfrissebb magyar felméréssel párhuzamban - az idő és a TM-elônyök ismeretének hiánya jellemzó. Az elérhetô előnyöknél a hatékonysági, termelékenységi szempontok számítanak elsődlegesnek. A támogató technológia és eszközök nem jelentenek problémát.

Szükség van egy egységes tudásmenedzsment-stratégia kialakítására, amely az üzleti stratégiában meghatározott kritikus tudásterületekre koncentrál. A meghatározott területeken fel kell mérni milyen tudásra, ismeretekre, tapasztalatokra van szükség, és azok rendelkezésre állnak-e. A felmérés eredményeitôl függően kell kialakítani a konkrét tudásmenedzsment-programokat. A programokban figyelembe kell venni, hogy minden esetben az üzleti célok megvalósulását kell támogatniuk. A tudásmenedzsment-projekteknek a már bevett projektmódszertanokat kell alkalmazni.

A tudásmenedzsment akkor hozhat tényleges versenyelónyt a bankoknak, ha azt az egész szervezet támogatja. Szükségesnek látom a tudásmenedzsmentben rejlő lehetôségek és elônyök minél jobb megismerését, majd pe- 
dig azok bemutatását a menedzsmentnek és a munkatársaknak. A tudásmegosztást támogató szervezeti kultúra a jövő́beni sikerek alapja. A tudás megosztása csak bizalmi légkörben jöhet létre, viszont ez sem elegendő, mert az alkalmazottakat meg kell győzni arról, hogy a tudás megosztása fontosabb, mint annak megtartása.

A felmérés tanulságai szerint a tudásmegosztást leginkább hátráltató tényezố az idő hiánya. Talán az a legfontosabb üzenetem a bankoknak, hogy a nagy rohanásban és versenyben hagyjunk elegendô idốt a tanulásra, a tudás megszerzésére, majd pedig támogassuk a tudás megosztását egy jól kialakított motivációs rendszer segítségével. Ne csak hangoztassuk, hogy a tudás a legfontosabb eróforrásunk, hanem próbáljunk meg tudatosan bánni ezzel a nagyon értékes vagyontárgyunkkal!

Cikk beérkezett: 2007. 3. hó

Lektori vélemény alapján átdolgozva: 2007. 7. hó

\section{Felhasznált irodalom}

Davenport, T.H. - Prusak, L. (2001): Tudásmenedzsment. Kossuth Kiadó, Budapest

KPMG (2000): Tudásmenedzsment Magyarországon (Felmérés - 2000). www.mkb.hu/red_publikaciok elemzestar KPMG2000tmriport.pdf Letöltés: 2005. 07. 03

KPMG (2002): Hol van a tudásmenedzsment a hype görbén? Tudásmenedzsment Magyarországon - (Felmérés - 2002). www.mfor.hu/cikk.php?article $=1240$

Letöltés: 2005. 11. 22

KPMG (2005): Tudásmenedzsment Magyarországon 2005/ 2006. www.doc.hu/tm/tmriport.pdf Letöltés: 2006. 07.03

Sveiby, K. E. (2001): Szervezetek új gazdasága: A menedzselt tudás. KJK-Kerszöv Kiadó, Budapest

\section{E SZÁMUNK SZERZŐI}

Dr. Hoványi Gábor, egyetemi magántanár, az MTA doktora, Pécsi Tudományegyetem, Dr. Meisel Sándor, tudományos munkatárs, MTA Világgazdasági Kutató Intézet, Hajnal György, PhD, tudományos főmunkatárs, Magyar Közigazgatási Intézet, Gulyás János, alkalmazásfejlesztési főosztályvezetô-helyettes, FHB Szolgáltató Zrt., JÁKI Erika, PhD-hallgató, Budapesti Corvinus Egyetem 